\title{
ELIMINATION OF ANTIBIOTICS BY PHOTOCATALYTIC METHODS
}

\author{
Anastasiya Kutuzova ${ }^{1,2}$, Tetiana Dontsova ${ }^{1}$, Maryna Davydova ${ }^{1}$ \\ ${ }^{1}$ National Technical University of Ukraine
}

“Igor Sikorsky Kyiv Polytechnic Institute”, dontsova@ua.fm, marynadavidova@gmail.com

${ }^{2}$ Leibniz Institute for Catalysis (LIKAT)

DOI: https://doi.org/10.20535/2218-930012021235229

\begin{abstract}
Antibiotics have been found in water bodies of different origin around the world, including natural waters. The presence of antibiotics in natural waters is already an important environmental problem, as they pose a potential threat to the environment. Analysis of the literature shows that photocatalytic methods are considered to be more promising than biological methods and adsorption processes for the treatment of water bodies contaminated with antibiotics and other pharmaceuticals. The aim of this study was to determine the efficiency of antibiotics removal (ciprofloxacin, sulfamethoxazole and trimethoprim) by photocatalytic methods over $\mathrm{TiO}_{2}$ photocatalyst modified with yttrium oxide. For this purpose, a commercial sample of $\mathrm{TiO}_{2} \mathrm{P} 25$ (Evonik) was modified, which was further characterized by X-ray diffraction and X-ray fluorescence analysis methods. The obtained data indicate the presence of yttrium in commercial P25 sample after modification. Studies on the removal of antibiotics from aqueous solutions by photocatalytic methods were carried out in three ways: employing modified photocatalyst; combination of photocatalyst and hydrogen peroxide, and the combination of photocatalyst with hydrogen peroxide and ozone. The results of research demonstrate high efficiency of photocatalytic methods in the oxidation of antibiotics in aqueous solutions, among which the greatest oxidation is achieved using the combination of heterogeneous photocatalyst, hydrogen peroxide and ozone.
\end{abstract}

Keywords: antibiotics, AOPs methods, photocatalysis, $\mathrm{TiO}_{2}$, yttrium modification

Received: 23 June 2021

Revised: 6 July 2021

Accepted: 6 July 2021

\section{Introduction}

The presence of antibiotics in the environment has become an important environmental problem, as these pharmaceuticals pose a potential threat to human health and the existence of biota [1]. A wide range of antibiotics, including ciprofloxacin (CIP), sulfamethoxazole (SMX) and trimethoprim (TMP), have already been identified in effluents of wastewater treatment plants, as well as in surface water, groundwater and drinking water in Europe and the United States because of their wide use, high resistance to oxidation and metabolism, etc. [2, 3].
Table 1 presents data on the concentration levels of these antibiotics in some countries. As can be seen from the table, concentration levels of these antibiotics in natural waters are quite high, and tend to increase from year to year. Unfortunately, due to the lack of legal and analytical bases in Ukraine, the content of pharmaceutical substances in water bodies is not monitored. However, this fact does not mean that antibiotics are absent in the natural water bodies of Ukraine; because of the obsolete wastewater treatment technologies, their content might be much higher.

Antibiotics are usually removed from aqueous solutions by such processes as biological treatment or adsorption [4-7]. 
However, other methods of antibiotics removal are widely studied in modern literature: electrocoagulation, membrane processes and photocatalytic methods or socalled AOPs [8-10]. Among the listed methods, photocatalytic methods using $\mathrm{TiO}_{2-}$ photocatalysts are the most promising, as the employment of solid catalysts based on $\mathrm{TiO}_{2}$ allows not only oxidation of antibiotics, but also their mineralization [11]. Commercial $\mathrm{TiO}_{2}$-based photocatalysts, which have high photocatalytic efficiency, include photocatalysts of the brands Evonik P25 and Hombikat UV-100.

Table 1. Average concentrations of TMP, CIP and SMX in wastewater [3]

\begin{tabular}{|c|c|c|}
\hline Antibiotic & Country & $\begin{array}{c}\text { Average } \\
\text { concentration of } \\
\text { antibiotics in } \\
\text { wastewater } \\
\left(\mathrm{ng} / \mathbf{d m}^{3}\right)\end{array}$ \\
\hline CIP & Europe & $20-95$ \\
\hline \multirow{3}{*}{ SMX } & Spain & 438 \\
\hline & Switzerland & 280 \\
\hline & Sweden & $70-233$ \\
\hline \multirow{2}{*}{ TMP } & France & $128-271$ \\
\hline & Switzerland & 200 \\
\hline
\end{tabular}

Despite the undeniable advantages of $\mathrm{TiO}_{2}$ photocatalysts, there are significant disadvantages, such as low quantum efficiency and low photocatalytic activity under visible light. The improvement of these properties is achieved by doping $\mathrm{TiO}_{2}$ with metal nanoparticles ( $\mathrm{Pt}, \mathrm{Au}, \mathrm{Ni}, \mathrm{Mo}, \mathrm{W}, \mathrm{Nb}$, $\mathrm{Mn}, \mathrm{Pd}, \mathrm{Fe}, \mathrm{Ce}, \mathrm{Co}$, etc.) or non-metals (S, C, $\mathrm{N}$, etc.) [12-17]. In addition, a promising way to increase photoactivity of the $\mathrm{TiO}_{2}$ photocatalysts is to create composites on its base [18-23]. In the scientific literature, modification of titanium (IV) oxide with rare earth metals has recently become very popular, among which yttrium is relatively cheap.

Thus, the aim of this work was to study the removal of antibiotics such as ciprofloxacin, sulfamethoxazole and trimethoprim by photocatalytic methods employing $\mathrm{TiO}_{2}$ photocatalyst modified with yttrium oxide.

\section{Materials and Methods}

The following reagents and materials were used in the work: hydrogen peroxide $\left(\mathrm{H}_{2} \mathrm{O}_{2}\right)$, antibiotics (ciprofloxacin $\mathrm{C}_{17} \mathrm{H}_{18} \mathrm{FN}_{3} \mathrm{O}_{3}$, trimethoprim $\mathrm{C}_{14} \mathrm{H}_{18} \mathrm{~N}_{4} \mathrm{O}_{3}$, sulfamethoxazole $\mathrm{C}_{10} \mathrm{H}_{11} \mathrm{~N}_{3} \mathrm{O}_{3} \mathrm{~S}$ ) and a commercial photocatalyst P25 Evonik, the characteristics of which are shown in Table 2.

Table 2. Characteristics of titanium (IV) oxide [24]

\begin{tabular}{|c|c|}
\hline Characteristics & Value \\
\hline $\mathrm{TiO}_{2}$ content $(\%)$ & 94 \\
\hline $\mathrm{pH}$ & $6.5-8.0$ \\
\hline Nanoparticle size $(\mathrm{nm})$ & $5-21$ \\
\hline
\end{tabular}

Modification of commercial titanium (IV) oxide with yttrium oxide $\left(\mathrm{Y}_{2} \mathrm{O}_{3}\right)$ was performed as follows. Yttrium nitrate $\left(\mathrm{Y}\left(\mathrm{NO}_{3}\right)_{3} \cdot 6 \mathrm{H}_{2} \mathrm{O}\right)$ of analytical qualification was chosen as a precursor. The calculated amount of yttrium nitrate (to obtain $1 \mathrm{wt} . \%$ of yttrium oxide) was mixed with $1 \mathrm{~g}$ of $\mathrm{TiO}_{2}$, and a certain amount of water was added. The obtained suspension was transferred to a stainless steel reactor with a Teflon liner, and heated to $160{ }^{\circ} \mathrm{C}$ for 12 hours. The reactor was then cooled and modified $\mathrm{TiO}_{2}$ was washed and separated in a centrifuge. 
The washed sample $\left(\mathrm{Y}_{2} \mathrm{O}_{3}-\mathrm{TiO}_{2}\right)$ was dried at $60{ }^{\circ} \mathrm{C}$ for 12 hours.

Modified samples of P25 were studied by X-ray fluorescence and X-ray diffraction methods of analysis. Chemical composition of the samples was determined using a precision analyzer EXPERT 3L (Ukraine). Diffraction analysis of the powder was performed using an X-ray diffractometer Rigaku Ultima IV (Japan) with $\mathrm{CuK} \alpha$ radiation $(40 \mathrm{~kW}, 30 \mathrm{~mA})$. The phase composition and size of the crystallites were determined and calculated using relevant software.

Studies of the antibiotics removal by photocatalytic methods were carried out using setup shown in Fig. 1. This experimental setup allows to study the influence of ozone, hydrogen peroxide, UV radiation and photocatalyst both separately and simultaneously.

As can be seen from Fig. 1, the setup consists of a tank for model water, a pump, a chamber with a UV lamp inside and an ozonator that supplies $\mathrm{O}_{3}$ to the ozone chamber. The system is looped and connected by tubes for water circulation in it.

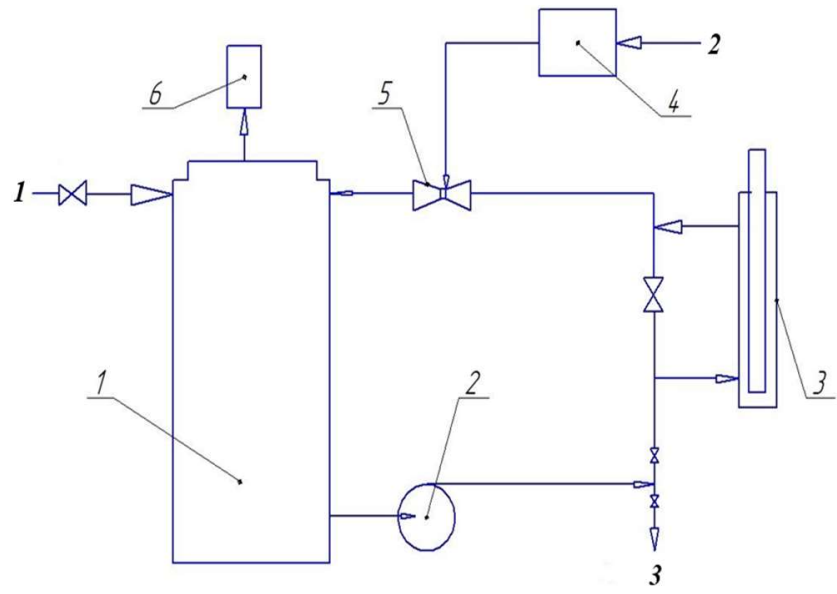

Fig. 1. Photocatalytic setup. Positions: 1 - tank, 2 - pump, 3 - UV lamp (257 nm), 4 -ozonator, 5 -faucet, 6 - gas collector; flows: 1 - model water with catalyst and hydrogen peroxide, 2 -air, 3 -treated water
The spectra of antibiotic solutions both before and after photocatalytic process were recorded on a UV/VIS Spectrophotometer $(220 \mathrm{~V} / 50 \mathrm{~Hz})$ in the wavelength range of 190 $800 \mathrm{~nm}$.

The degree of removal was determined by the formula [25]:

$$
X=\frac{A_{0}-A_{k}}{A_{0}} * 100 \%,
$$

where $A_{0}$ and $A_{k}$ - are initial and resulting optical densities of the antibiotic solution by characteristic wavelength.

\section{Results and Discussion}

The results of the characterization of titanium (IV) oxide modified with yttrium oxide (sample $\mathrm{Y}_{2} \mathrm{O}_{3}-\mathrm{TiO}_{2}$ ) and unmodified P25 (for comparison) are presented in Fig. 2 and in Table 3.

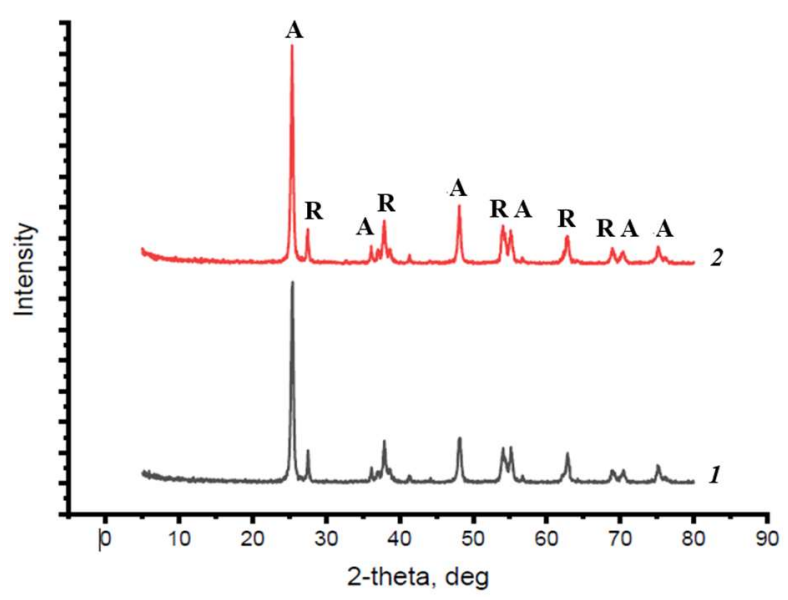

Fig. 2. XRD patterns of the samples: $1-\mathrm{P} 25,2-\mathrm{Y}_{2} \mathrm{O}_{3}-\mathrm{TiO}_{2}$

As can be seen from Fig. 2, XRD patterns are identical, and only the peaks associated with P25 (90\% anatase and 10\% rutile; standard cards № 00-021-1276 for rutile, № 00-021-1272 for anatase) are clearly observed. Yttrium oxide phase was not detected. 
Even though $\mathrm{Y}_{2} \mathrm{O}_{3}$ phase has not been detected, the chemical composition (Table 3) indicates the presence of yttrium in modified sample of $\mathrm{TiO}_{2}$. In terms of oxide, it is 0.92 wt. $\%$ that is very close to theoretically calculated.

Table 3. Chemical composition of the sample

\begin{tabular}{|c|c|c|}
\hline Sample & $\mathbf{T i}, \boldsymbol{\%}$ & $\mathbf{Y ,} \%$ \\
\hline $\mathrm{P} 25$ & 100 & - \\
\hline $\mathrm{Y}_{2} \mathrm{O}_{3}-\mathrm{TiO}_{2}$ & 1.2 & 98.8 \\
\hline
\end{tabular}

Studies of the antibiotics removal: CIP and co-trimoxazole (SMX + TMP) from model aqueous solutions by photocatalytic methods were carried out in three ways: employing $\mathrm{Y}_{2} \mathrm{O}_{3}-\mathrm{TiO}_{2}$ photocatalyst only; employing $\mathrm{Y}_{2} \mathrm{O}_{3}-\mathrm{TiO}_{2}$ photocatalyst in the presence of hydrogen peroxide; employing $\mathrm{Y}_{2} \mathrm{O}_{3}-\mathrm{TiO}_{2}$ photocatalyst in the presence of hydrogen peroxide with the addition of ozone.

Fig. 3 shows the spectra of CIP solution before and after the photocatalytic process over $\mathrm{Y}_{2} \mathrm{O}_{3}-\mathrm{TiO}_{2}$ photocatalyst in the absence of hydrogen peroxide (spectrum 2, Fig. 3) and in its presence (spectrum 3, Fig. 3). It can be seen that intensities of the antibiotic peaks become much lower after the photocatalytic process both in the case of $\mathrm{Y}_{2} \mathrm{O}_{3}-\mathrm{TiO}_{2}$ usage and usage of photocatalyst combination with hydrogen peroxide. The greater degree of oxidation is observed for the employment of combination of $\mathrm{Y}_{2} \mathrm{O}_{3}-\mathrm{TiO}_{2}$ and oxidant (Table 4). This is explained by the formation of more $\mathrm{OH}^{\bullet}$ radicals in this case [10].

Fig. 4 illustrates the spectra of the initial co-trimoxazole solution (spectrum 1, Fig. 4) and of the solution after the photocatalytic process using a combination of the catalyst with hydrogen peroxide (spectrum 2, Fig. 4).

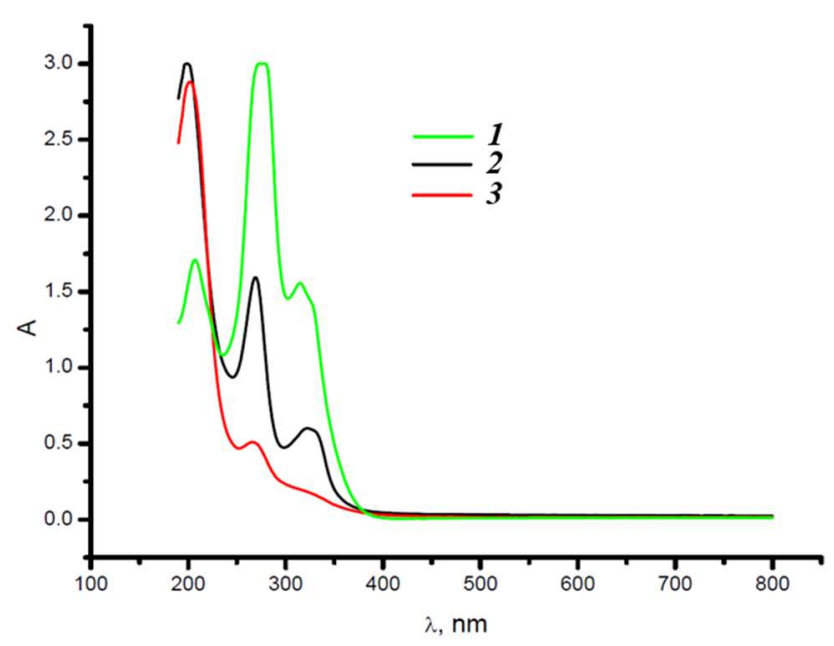

Fig. 3. Spectra of CIP solution before photocatalytic process (1) and after (2, 3): 1 initial CIP solution $\left(50 \mathrm{mg} / \mathrm{dm}^{3}\right), 2$ - solution spectrum after photocatalytic process over $\mathrm{Y}_{2} \mathrm{O}_{3}-\mathrm{TiO}_{2}, 3$ - solution spectrum after photocatalytic process over $\mathrm{Y}_{2} \mathrm{O}_{3}-\mathrm{TiO}_{2}$ in the presence of hydrogen peroxide

Table 4. Degrees of antibiotics oxidation in aqueous solutions by photocatalytic methods

\begin{tabular}{|c|c|c|c|}
\hline \multirow[b]{2}{*}{ Antibiotic } & \multicolumn{3}{|c|}{ Oxidation degrees, \% } \\
\hline & $\begin{array}{l}\mathrm{Y}_{2} \mathrm{O}_{3}- \\
\mathrm{TiO}_{2}\end{array}$ & $\begin{array}{l}\mathrm{Y}_{2} \mathrm{O}_{3}- \\
\mathrm{TiO}_{2} \\
\mathrm{H}_{2} \mathrm{O}_{2}\end{array}+$ & $\begin{array}{l}\mathrm{Y}_{2} \mathrm{O}_{3}- \\
\mathrm{TiO}_{2}+ \\
\mathrm{H}_{2} \mathrm{O}_{2}+ \\
\mathrm{O}_{3}\end{array}$ \\
\hline CIP & 52 & 87 & 100 \\
\hline $\begin{array}{l}\text { Co- } \\
\text { trimoxazole } \\
(\mathrm{SMX} \\
\mathrm{TMP})\end{array}$ & 56 & 92 & 100 \\
\hline
\end{tabular}

As in the case of CIP removal, there is a significant reduction in the intensity of the antibiotic peaks and according to the data in Table 4, a greater degree of oxidation is also observed for the combination of the catalyst with hydrogen peroxide. 


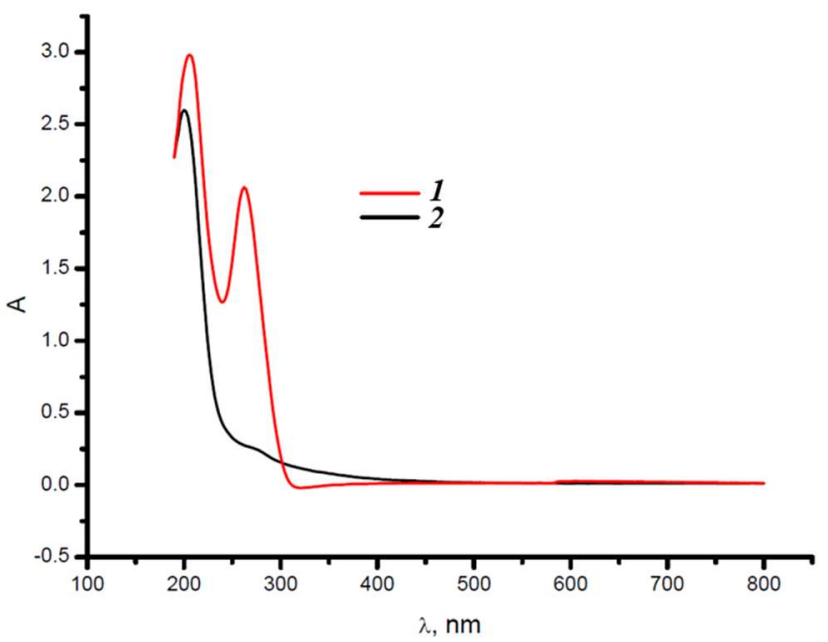

Fig. 4. Spectra of $S M X+T M P$ (cotrimoxazole) solution before photocatalytic process (1) and after (2): 1 - initial cotrimoxazole solution $\left(50 \mathrm{mg} / \mathrm{dm}^{3}\right), 2$ solution spectrum after photocatalytic process over $\mathrm{Y}_{2} \mathrm{O}_{3}-\mathrm{TiO}_{2}$ in the presence of hydrogen peroxide

In Table 4, degrees of oxidation of antibiotics (CIP and co-trimoxazole) are given: using $\mathrm{Y}_{2} \mathrm{O}_{3}-\mathrm{TiO}_{2}$ photocatalyst; combination of $\mathrm{Y}_{2} \mathrm{O}_{3}-\mathrm{TiO}_{2}$ photocatalyst and hydrogen peroxide; combination of $\mathrm{Y}_{2} \mathrm{O}_{3}$ $\mathrm{TiO}_{2}$ photocatalyst and hydrogen peroxide with the addition of ozone.

Analysis of the obtained data (Table 4) indicates complete degradation of antibiotics with a concentration of $50 \mathrm{mg} / \mathrm{L}$ using $\mathrm{Y}_{2} \mathrm{O}_{3}-$ $\mathrm{TiO}_{2}$ photocatalyst in the presence of hydrogen peroxide and the addition of ozone.

\section{Conclusions}

Studies have shown the effectiveness of antibiotics removal (ciprofloxacin, sulfamethoxazole and trimethoprim) by various combinations of photocatalytic methods using $\mathrm{TiO}_{2}$ photocatalyst modified with yttrium oxide.

Characterization of modified and unmodified commercial sample of $\mathrm{TiO}_{2}-\mathrm{P} 25$
(Evonik) by X-ray diffraction and X-ray fluorescence methods of analysis revealed that after modification with yttrium oxide, the latter is present in the sample.

It was shown that the most effective photocatalytic system is the combination of heterogeneous photocatalyst, hydrogen peroxide and ozone, which oxidizes antibiotics in aqueous solutions by $100 \%$ at their initial concentration of $50 \mathrm{mg} / \mathrm{L}$.

It was confirmed that the use of photocatalytic methods is a promising solution for the treatment of water bodies containing antibiotics.

\section{Acknowledgments}

We are grateful to the National Research Foundation of Ukraine "Support for research of leading and young scientists" for funding the project (project registration number 2020.02/0024).

\section{References}

1. Zhang, H.; Du M.; Jiang, H.; Zhang, D.; Lin, L.; Ye, H.; Zhang, X. "Occurrence, seasonal variation and removal efficiency of antibiotics and their metabolites in wastewater treatment plants, Jiulongjiang River Basin, South China". J. Environ. Sci.: Processes Impacts, 2015, 171, 225-234.

2. Doll, T.E.; Frimmel, F. "Removal of selected persistent organic pollutants by heterogeneous photocatalysis in water". J. Catalysis Today, 2015, 101, 195-202.

3. Johnson, A.C.; Keller, V.; Dumont, E.; John, P. "Sumpter. Assessing the concentrations and risks of toxicity from the antibiotics ciprofloxacin, sulfamethoxazole, trimethoprim and erythromycin in European rivers". J. The Science of the total environment, 2015, 511, 747-755.

4. Zhu, T.; Su, Z.; Lai, W.; Zhang, Y., Liu, Y. "Insights into the fate and removal of antibiotics and antibiotic resistance genes using biological wastewater treatment technology". J. Science of the Total Environment, 2021, 776, 145906. 
5. Zheng, C.; Zheng, H.; Hu, C.; Wang, Y.; Wang, Y.; Zhao, C.; Ding, W.; Sun, Q. "Structural design of magnetic biosorbents for the removal of ciprofloxacin from water". J. Bioresource Technology, 2019, 296, 122288.

6. Cuerda-Correa E.M.; Alexandre-Franco M.F., Fernández-González C. "Advanced Oxidation Processes for the Removal of Antibiotics from Water. An Overview”. J. Water, 2020, 12(1), 102.

7. Scariaa, J.; Anupamaa, P.; Nidheesh, V. "Tetracyclines in the environment: An overview on the occurrence, fate, toxicity, detection, removal methods, and sludge management". J. Science of The Total Environment, 2021, 771, 145291.

8. Ates H.; Dizge N.; Yatma H.C. "Combined process of electrocoagulation and photocatalytic degradation for the treatment of olive washing wastewater". J. Water Sci Technol, 2017, 75 (1), 141-154.

9. Barana, W.; Adameka, E.; Jajkoab, M., Sobczakc, A. "Removal of veterinary antibiotics from wastewater by electrocoagulation". J. Chemosphere, 2018, 194, 381-389.

10. Dontsova T.A. "Characterization and prospects of titanium (iv) oxide in water treatment". J. Water and Water Purification Technologies, 2015, 16.

11. Kutuzova, A.; Dontsova, T.; Kwapinski, W. "Application of $\mathrm{TiO}_{2}$-Based Photocatalysts to Antibiotics Degradation: Cases of Sulfamethoxazole, Trimethoprim and Ciprofloxacin”. J. Catalysts, 2021, $11(6), 728$.

12. Khairy, M., Zakaria, W. "Effect of metaldoping of $\mathrm{TiO}_{2}$ nanoparticles on their photocatalytic activities toward removal of organic dyes". Egyptian Journal of Petroleum, 2014, 23 (4), 419-426.

13. Sescu, A.M.; Favier, L.; Lutic, D.; SotoDonoso, N.; Ciobanu, G.; Harja, M. " $\mathrm{TiO}_{2}$ Doped with Noble Metals as an Efficient Solution for the Photodegradation of Hazardous Organic Water Pollutants at Ambient Conditions". J. Water, 2021, 13 (1), 19

14. Dontsova, T.A.; Kutuzova, A.S.; Bila, K.O.; Kyrii, S.O.; Kosogina, I.V., Nechyporuk, D.O. "Enhanced Photocatalytic Activity of $\mathrm{TiO}_{2} / \mathrm{SnO}_{2}$ Binary Nanocomposites". Journal of Nanomaterials, 2020, 13.

15. Khlyustova, A.; Sirotkin, N.; Kusova, T.; Kraev, A.; Titova, V.; Agafonov, A. "Doped $\mathrm{TiO}_{2}$ : The effect of doping elements on photocatalytic activity". J. Mater. Adv., 2020, 1, 1193-1201.
16. McManamon, C.; Delaney, P., Morris, M.A. "Photocatalytic properties of metal and non-metal doped novel sub $10 \mathrm{~nm}$ titanium dioxide nanoparticles on methyl orange". Journal of Colloid and Interface Science, 2013, 411, 169-172.

17. Ansari S.A.; Khan M.M.; Ansaric M.O.; Cho M.H. "Nitrogen-doped titanium dioxide (N-doped TiO2) for visible light photocatalysis". J. New J. Chem., 2016, 40, 3000-3009.

18. Kutuzova, A.S., Dontsova T.A. "Synthesis, characterization and properties of titanium dioxide obtained by hydrolytic method". Proceedings of the 2017 IEEE 7 th International Conference on nanomaterials: Applications and Properties, 2017, 286-290.

19. Song, Y.; Zhanga, J.; Yanga, L.; Caoa, S.; Yanga, H.; Zhanga, J.; Jianga, L.; Dan, Y.; Le, R.P.; Nguyen T.P. "Photocatalytic activity of $\mathrm{TiO} 2$ based composite films by porous conjugated polymer coating of nanoparticles". J. Materials Science in Semiconductor Processing, 2016, 42, 54-57.

20. Li, Z.; Cao, F.; Wang, L.; Chena, Z., Ji, X. "A novel ternary $\mathrm{MoS}_{2} / \mathrm{MoO}_{3} / \mathrm{TiO}_{2}$ composite for fast photocatalytic degradation of rhodamine $\mathrm{B}$ under visible-light irradiation". New J. Chem., 2020, 44, 537542.

21. Hamidi F.; Aslani F. " $\mathrm{TiO}_{2}$-based Photocatalytic Cementitious Composites: Materials, Properties, Influential Parameters, and Assessment Techniques". J. Nanomaterials, 2019, 9 (10), 1444.

22. Falah, M., MacKenzie, K.J.D. "Photocatalytic Nanocomposite Materials Based on Inorganic Polymers (Geopolymers): A Review". J. Catalysts, 2020, 10 (10), 1158.

23. Khalid, N.R. " $\mathrm{TiO}_{2}$-Graphene-Based Composites: Synthesis, Characterization, and Application in Photocatalysis of Organic Pollutants". $J$. Micro and Nanomanufacturing, 2018, 2, 95-122.

24. Ашуркевич, К.В.; Николаенко, И.А.; Борисенко, В.Е. “Формирование и свойства фотокаталитически толстых пленок с диоксидом титана”. Доклады БГУИР, 2012, 6 (68), 50-55.

25. Kutuzova, A.S.; Dontsova, T.A. "Characterization and properties of $\mathrm{TiO}_{2}-\mathrm{SnO}_{2}$ nanocomposites, obtained by hydrolysis method". $J$. Appl Nanosci, 2019, 9, 873-880. 


\title{
ВИЛУЧЕННЯ АНТИБІОТИКІВ ФОТОКАТАЛІТИЧНИМИ МЕТОДАМИ
}

\author{
А.С. Кутузова $a^{1,2}$, Т.А. Донцова 1 , М.Ю. Давидова ${ }^{1}$ \\ ${ }^{1}$ КПІ ім. Ігоря Сікорського \\ ${ }^{2}$ Лейбніцький інститут каталізу
}

\begin{abstract}
Антибіотики знайдені у водних об'єктах різного генезису по усьому світу, серед яких й природні води. Присутність антибіотиків у природних водах на сьогоднішній день вже $\epsilon$ важливою екологічною проблемою, оскільки вони становлять потенційну загрозу навколишньому середовищу. Аналіз літературних даних свідчить, щзо фотокаталітичні методи вважаються більш перспективними у порівнянні з біологічними методами очищенням та прочесами адсорбиії для знешкодження водних об'єктів, що містять антибіотики та інші фармацевтичні препарати. Метою даного наукового дослідження було встановлення ефективності вилучення антибіотиків (ципрофлоксацину, сульфаметоксазолу та триметоприму) фотокаталітичними методами за участі модифікованого оксидом ітрію Ті ${ }_{2}$. Для изього було проведено модифікацію комериійного зразку $\mathrm{TiO}_{2} \quad \mathrm{P} 25$ (Evonik), який далі охарактеризовано дифракційним та рентгенофлуоресиентним методами аналізу. Одержані дані, вказують на присутність ітрію в комериійному зразку Р25 після модифікаиії. Дослідження щзодо вилучення антибіотиків з водних розчинів фотокаталітичними методами реалізовано трьома шляхами, а саме, за участі модифікованого фотокаталізатору, комбінації фотокаталізатору з одночасним використанням пероксиду водню та комбінації фотокаталізу із застосуванням пероксиду водню та озону. Результати досліджень свідчать про високу ефективність фотокаталітичних методів для окиснення антибіотиків з водних розчинів, серед яких найбільш глибоке окиснення досягається використання комбінації гетерогенного фотокаталізатору, пероксиду водню та озону.
\end{abstract}

Ключові слова: антибіотики, нетрадиційні методи очищення, фотокаталіз, $\mathrm{TiO}_{2}$, модифікація ітрієм 